Document downloaded from:

http://hdl.handle.net/10251/94530

This paper must be cited as:

Galán, E.; Sanchis Jiménez, EM.; Estellés, F.; Calvet, S.; Del Prado, A. (2016). Heat stress effects in milk yield and milk traits at farm scale. Advances in Animal Biosciences. 7(3):238239. doi:10.1017/S2040470016000261

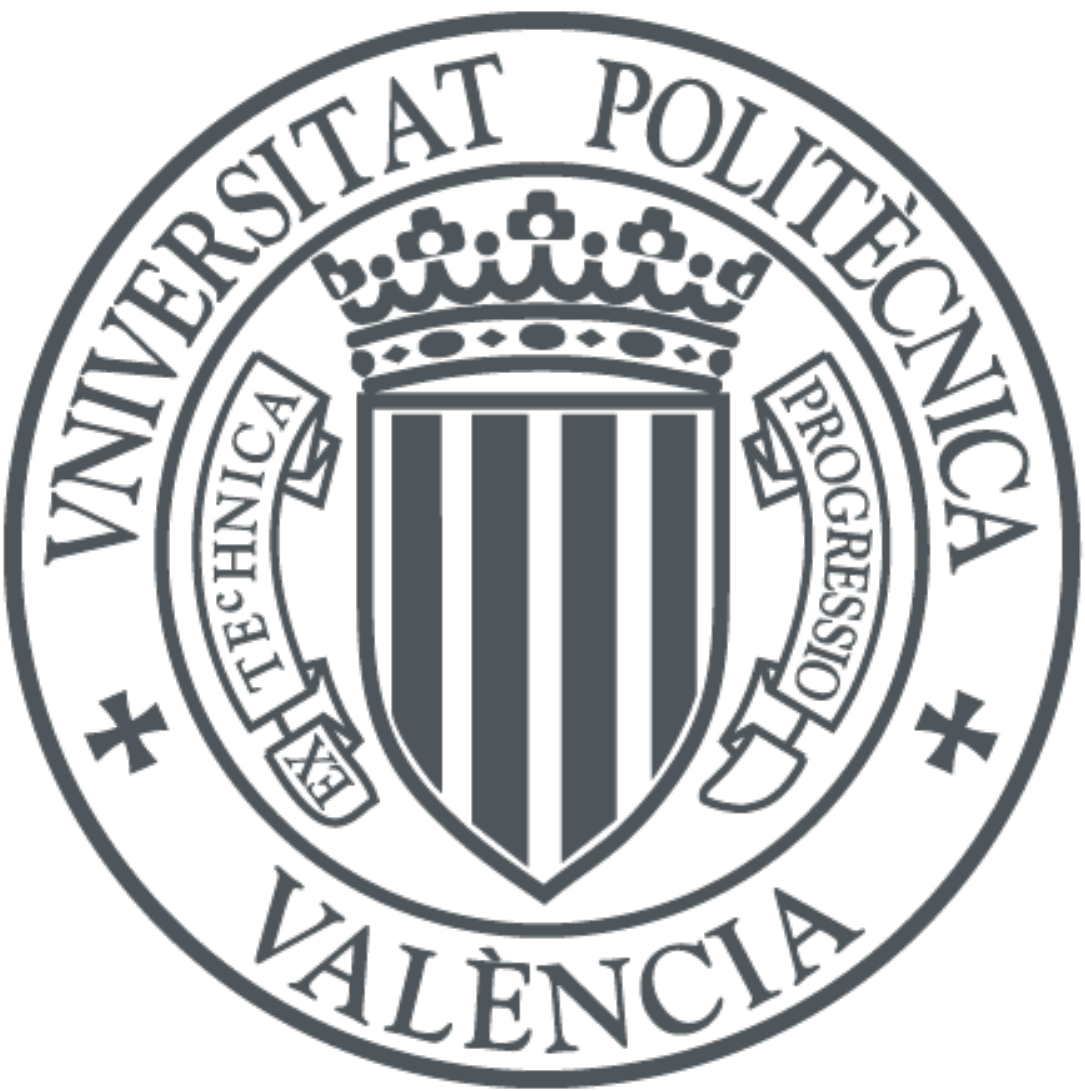

The final publication is available at

https://doi.org/10.1017/S2040470016000261

Copyright Cambridge University Press

Additional Information 


\section{Heat stress effects in milk yield and milk traits at farm scale}

2 E. Galán*1 ${ }^{1}$ E. Sanchis ${ }^{2}$, F. Estellés ${ }^{2}$, S. Calvet ${ }^{2}$ and A. del Prado ${ }^{1}$

$3{ }^{1}$ Basque Centre for Climate Change (BC3), Edificio Sede $N^{0} 1$, Planta $1^{\text {a }}$, Parque científico de

4 UPVIEHU, Barrio Sarriena s/n 48940 Leioa (Bizkaia), Spain

$5{ }^{2}$ Institute of Animal Science and Technology, Universitat Politècnica de València (UPV), Camino

6 de Vera, s/n, 46022, Valencia, Spain

$7 \quad$ Corresponding author: Elena Galan E-mail: elena.galan@bc3research.org

\section{Keywords}

9 Dairy, heat stress, THI, milk yield, calving seasonality

\section{Introduction}

12 Climate change will aggravate the effects of hot weather in welfare, health, performance and 13 survival of farm animals (Segnalini et al., 2013). Few farm whole models (e.g. Rotz et al., 2015; del

14 Prado et al., 2011a) have been used for assessing climate change impacts, adaptation and 15 mitigation (Del Prado et al., 2013). In the framework of the ERANET+ project OptiBarn, our aim is

16 to present a risk assessment for three potential impacts of climate change at farm-scale in dairy 17 cow systems: welfare, economic costs and greenhouse gas emissions. Our first objective is to 18 evaluate the effects of heat stress in a baseline scenario to incorporate a valid sub-model to allow 19 SIMSDAIRY (del Prado et al., 2011b) predict heat stress and introduce the effects of farm-level 20 adaptation measures.

\section{Material and methods}

23 Our initial case study is located in the south of Spain. As in most semi-arid areas, barns are loose 24 and open and management practices to face summer heat stress are already implemented. It is 25 an intensive system that has large herd sizes of high yielding Holstein cows without access to 26 grass although the barn has a yard with some shade. A literature review was carried out to assess 27 the state of the art in understanding the effects on milk yield and milk traits of heat stress in permanently housed dairy cows.

30 We used meteorological 20-years (1995-2014) data from Valencia airport Agencia Estatal de 31 Meteorología (AEMET) to calculate the daily Temperature Humidity Index (THI):

$$
\mathrm{THI}=(1.8 \times \mathrm{Tdb}+32)-(0.55-0.55 \times \mathrm{RH} / 100) \times(1.8 \times \mathrm{Tdb}-26) \text {, }
$$


33 Where $\mathrm{Tdb}$ : dry bulb temperature $\left({ }^{\circ} \mathrm{C}\right)$ and $\mathrm{RH}$ : relative humidity (\%).

34 We simulated the effects of heat stress in milk production (St-Pierre et al. 2003) in a farm of 100 35 cows in southern Spain with two scenarios of seasonality. "No seasonality" scenario assumes 36 constant calving season. "Seasonality" scenario assumes that lactation of 25 cows started in 37 October and 75 in November to avoid insemination and lactation peaks in summer months. Prices 38 are the monthly mean for Spain for the years 1995-2014 (Milk market observatory, 2016).

\section{Results and discussion}

41 Mean daily THI in July and August between 1995 and 2014 is above the threshold of 73 THI for 42 heat stress described for Spanish dairy cows (Carabaño et al. 2016), and it is above the general 43 threshold for high yielding dairy cows of 69 THI (Zimbelman et al., 2009) from June to September.
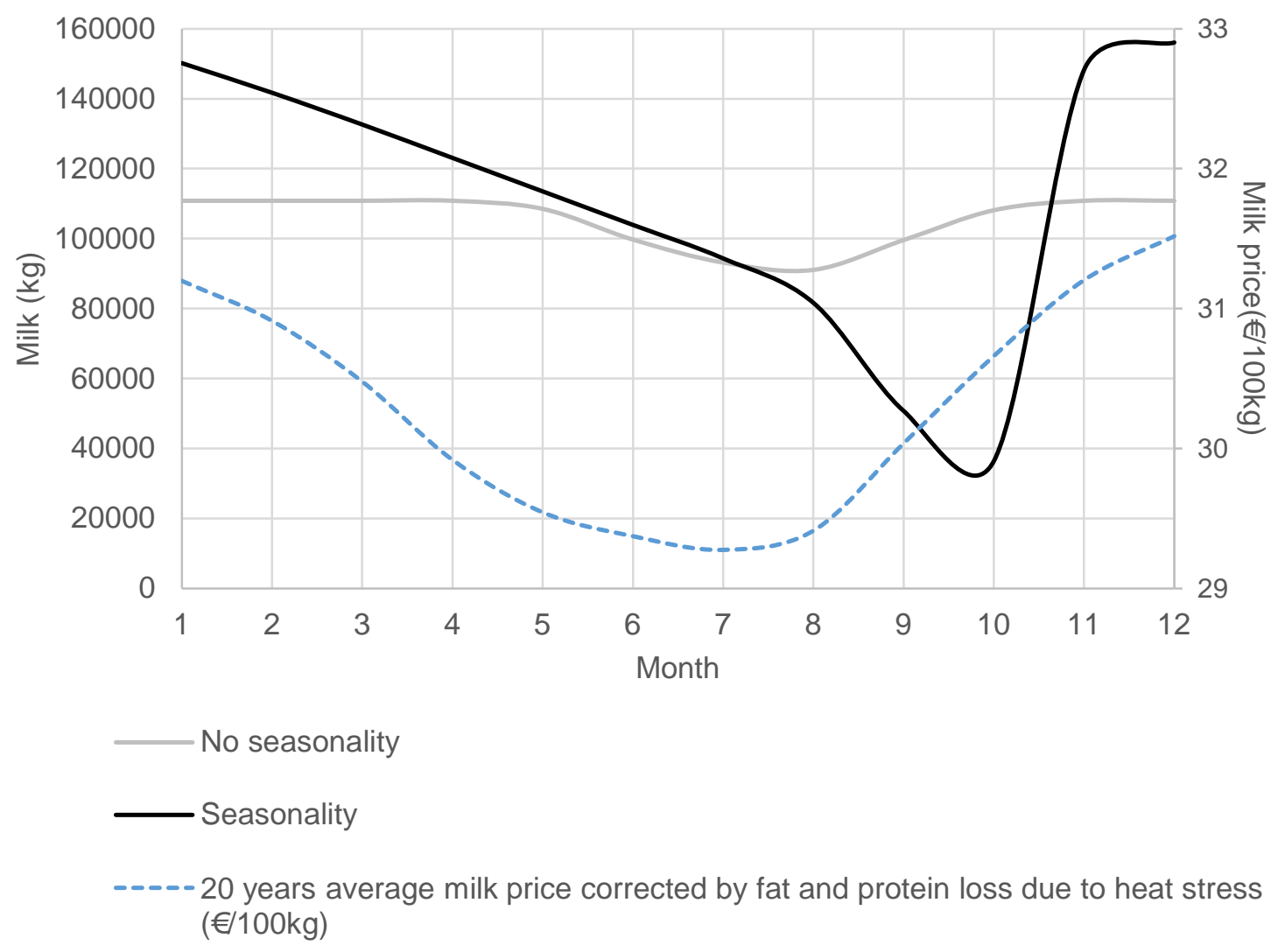

45 Figure 1. Farm production scenarios in southern Spain. Heat stress effects according to St-Pierre et al. 46 (2003) for a herd of 100 cows located in the south of Spain. Prices are the monthly average for Spain for the 47 years 1995-2014 (Milk market observatory, 2016).

48 The THI in the area is expected to increase in the next years (Segnalini et al., 2013). The use of $49 \mathrm{THI}$ has been criticized as it does not account for solar radiation or wind speed, and other 
50 indicators combining different climatic variables have been proposed (Hammami et al., 2013).

51 However, we used it for the purpose of this study as we did not find a better approximation for farm

52 scale in literature.

53 In Figure 1, the seasonality scenario produces annually 5.3\% more milk than the scenario without 54 seasonality because cows exposed to highest THI are either dry or in late lactation. Prices for the 55 last 20 years have been lower in summer months. Hence, the difference of annual farm income 56 increases up to $5.7 \%$ when combined with the effect on losses in percentage of fat and protein

57 (calculated from Carabaño et al. 2016) in the warmest months. In warm areas of Spain, it is 58 common to have fans functioning permanently when temperature is above $23-25^{\circ} \mathrm{C}$; also it is 59 common to manage the herd in order to avoid lactation peaks and insemination periods in the 60 warmest months, when conception rates are affected by warm temperatures (Schüller et al., 61 2014). However, in the present study neither the effects of THI on conception rates, nor other 62 factors that contribute to farm economics such as health, death rates or potential variation in feed 63 prices were simulated. Including these variables might be expected to increase the differences 64 between the two scenarios shown here. Moreover, the interaction of THI with welfare and 65 farm-level emissions is yet unknown.

\section{Conclusion}

68 In semi-arid climates, the combination of heat abatement structures with herd management 69 techniques (such as seasonality of calving) reduces the effects of heat stress on milk yield. Our 70 results show the potential for adaptation measures to heat stress at farm scale. Future scenarios 71 are needed to predict the effects of climate change on farm economics, also taking into account reproductive performance, welfare, death rates and farm greenhouse gas emissions.

\section{Acknowledgements}

75 This study is part of the Optibarn project and is funded by the Instituto Nacional de Investigación y 76 Tecnología Agraria y Alimentaria (INIA) through the research grant 618105 FACCE Era Net Plus Food Security, Agriculture, Climate Change ERA-NET plus.

\section{References}

81 Carabaño MJ, Logar B, Bormann J, Minet J, Vanrobay, M-L, Díaz C, Tychon B, Gengler N, Hammami H 3798-3814. 
Del Prado A, Shepherd A, Wu L, Topp C, Moran D, Tolkamp B, Gallejones P and Chadwick D 2011a. Modelling the effect of climate change only on environmental pollution losses from UK dairy systems. Nitrogen and Global Change: Key Findings - Future Challenges

Del Prado A, Misselbrook T, Chadwick D, Hopkins A, Dewhurst RJ, Davison P, Butler A, Schröder J, Scholefield D 2011b. SIMSDAIRY: A modelling framework to identify sustainable dairy farms in the UK. Framework description and test for organic systems and $\mathrm{N}$ fertiliser optimisation. Science of the Total Environment 409, 3993-4009.

Del Prado A, Crosson P, Olesen JE and Rotz A 2013. Whole-farm models to quantify greenhouse gas emissions and their potential use for linking climate change mitigation and adaptation in temperate grassland ruminant-based farming systems. Animal 7 (suppl.2), 373-385

Hammami H, Bormann J, M'hamdi N, Montaldo HH, Gengler N 2013 Evaluation of heat stress effects on production traits and somatic cell score of Holsteins in a temperate environment. Journal of Dairy Science 96, 1844-1855.

Milk market observatory. EU PRICES of COW'S RAW MILK. Regulation (EC) No 479/2010 Article 2 [Retrieved on 15 May 2016 http://ec.europa.eu/agriculture/milk-market-observatory/index_en.htm]

Rotz CA, Skinner RH, Stoner AMK, Hayhoe K 2015. Farm Simulation Can Help Dairy Production Systems Adapt to Climate Change, in: Advances in Agricultural Systems Modeling. American Society of Agronomy, Crop Science Society of America and Soil Science Society of America, Inc.

Schüller LK, Burfeind O, Heuwieser W 2014. Impact of heat stress on conception rate of dairy cows in the moderate climate considering different temperature-humidity index thresholds, periods relative to breeding, and heat load indices. Theriogenology 81, 1050-1057.

Segnalini M, Bernabucci U, Vitali A, Nardone A, Lacetera N 2013. Temperature humidity index scenarios in the Mediterranean basin. International Journal of Biometeorology 57, 451-458.

St-Pierre NR, Cobanov B, Schnitkey G 2003. Economic losses from heat stress by US livestock industries. Journal of Dairy Science 86, E52-E77.

Zimbelman RB, Rhoads RP, Rhoads ML, Duff GC, Baumgard LH, Collier RJ 2009. A Re-Evaluation of the Impact of Temperature Humidity Index (THI) and Black Globe Humidity Index (BGHI) on Milk Production in High Producing Dairy Cows. Proceedings of the Southwest Nutrition and Management Conference, 26-27 February 2009, Tempe, Arizona, 158-168. 